\title{
16 \\ Transaction costs in agri-environment schemes
}

Stuart Whitten and Anthea Coggan

\section{Key lessons}

- Transaction costs of agri-environment schemes include the time, effort and expense of gathering information, identifying projects, negotiating contracts, and monitoring and compliance.

- They are incurred by participants, scheme proponents and administrators and can be significant, impacting not only on total scheme costs, but also on efficiency.

- Transaction costs are directly related to both scheme design and scheme implementation.

- Considering transaction costs does not necessarily mean reducing them - indeed, efficient program design may require increased transaction costs in order to more confidently deliver the desired outcome.

\section{Transaction costs - a necessary evil?}

Agri-environmental schemes, which are designed to support private land managers in delivering positive environmental outcomes, involve a range of costs to government and landholders. These include the direct 
costs from implementing desired agri-environmental management actions (materials, labour, and equipment), opportunity costs from changes to agricultural production, transformation costs (physical or other changes to the business to allow the management actions to be implemented), and transaction costs (arising from program design, implementation, and management). While direct costs are generally highly visible and well reported, transformation and transaction costs are often less obvious and are neglected in analyses. Transaction costs are a particularly pervasive, yet relatively recent concept in economics, important in the design and implementation of agri-environment schemes.

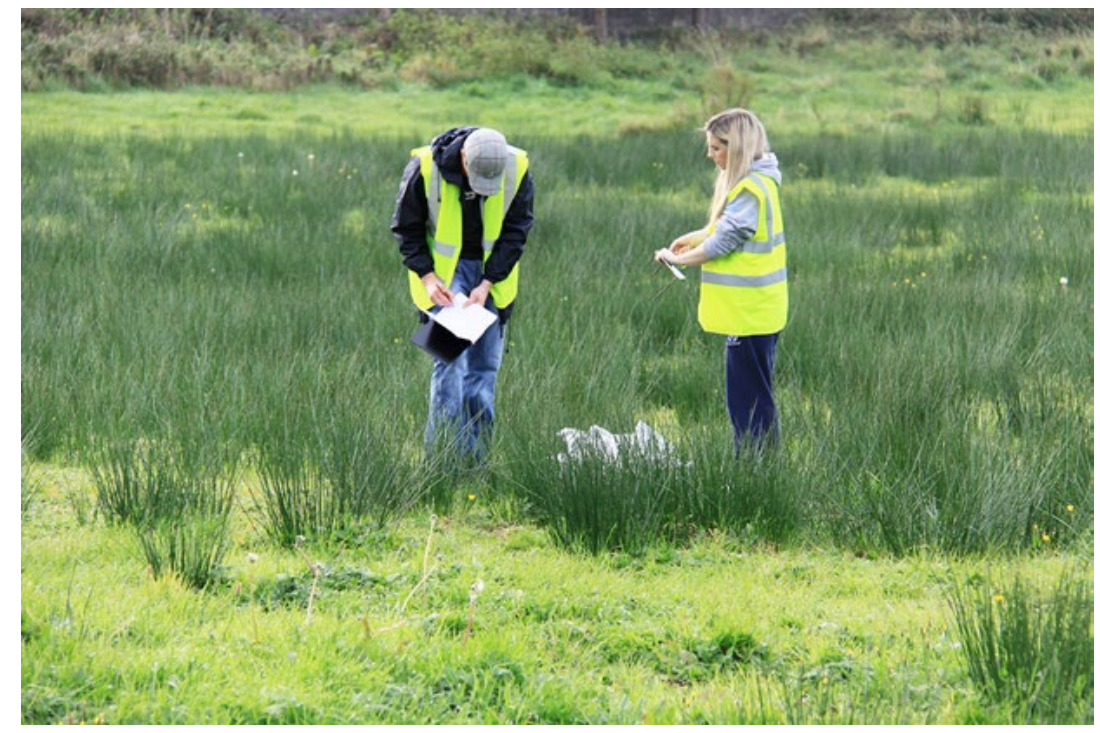

Figure 16.1: There are numerous transaction costs associated with agri-environment schemes, including compliance monitoring and program evaluation.

Source: Photo by Declan Feeney available at www.flickr.com/photos/ardboline/9797787304 under a Creative Commons Attribution 2.0.

So what are these transaction costs? There are three overlapping definitions that apply somewhat differently depending on the particular environmental issue that a scheme is concerned with. From the perspective of the organisations involved in an agri-environment scheme, transaction costs relate to the costs of gathering information, negotiating or otherwise identifying who to pay, who to be paid by, and how much, as well as contracting, monitoring, and enforcement 
(Williamson 1998). These costs apply to the scheme proponent (usually government agencies or third parties engaged by government) and to firms, individuals (i.e. landholders), or other agents engaging in the scheme (McCann et al. 2005). They are generally held to include the direct costs of designing the scheme, but a narrower definition applied by North (1990, pp. 1-35) limits transaction costs to the costs of specifying and supporting the contract. This definition is most relevant in direct comparison of existing agri-environment schemes designed for the same purpose, where the costs of designing the instrument can be considered sunk or legacy costs, and evaluation only applies to future efficiency.

The third definition applies when social coordination is required to produce the desired outcome - such as biodiversity corridors or management of a common water resource (Reeson et al. 2011). The costs of social coordination, through collective action, consultative planning or other measures would then be included as a transaction cost (Ostrom 1990). While such coordinated action is by no means unusual in agri-environmental settings, most schemes are designed and intended to interact with individuals separately, even where a socially coordinated outcome is intended. These schemes are also sufficiently novel that they are not generally available off the shelf and involve at least some investment in refining their design and implementation for a particular context. The relevant transaction costs in the most common agri-environmental settings include design, implementation, and administration costs across proponents and participants. Design and implementation costs do not generally involve changes to the institutional environment and legal settings when the scheme is limited to payments to landholders for existing rights, but may if the scheme involves creation of tradeable rights that are then purchased - such as in new water markets or biodiversity offset schemes.

Transaction costs may be monetary costs (e.g. administrative staff, legal advice on contracts, cost of travel to meetings to discuss the transaction), opportunity costs (e.g. time invested in exploring incentive options that would otherwise have generated an income), and non-monetary costs (e.g. time spent managing business affairs instead of recreation). A summary of the likely range of transaction costs in agri-environment schemes, drawing in particular on Coggan et al. (2010), is set out in Table 16.1. 


\section{Table 16.1: Likely transaction costs encountered in agri-environment schemes.}

\begin{tabular}{|c|c|c|c|}
\hline $\begin{array}{l}\text { Type of } \\
\text { transaction cost }\end{array}$ & When it is incurred & $\begin{array}{l}\text { Scheme proponent and } \\
\text { administrator costs }\end{array}$ & $\begin{array}{l}\text { Payment } \\
\text { recipient costs }\end{array}$ \\
\hline $\begin{array}{l}\text { Information about } \\
\text { the problem }\end{array}$ & $\begin{array}{l}\text { Well before the } \\
\text { scheme has been } \\
\text { decided upon (even } \\
\text { many years before). }\end{array}$ & $\begin{array}{l}\text { Identifying, collecting, } \\
\text { and analysing data about } \\
\text { the problem and potential } \\
\text { solutions. }\end{array}$ & $\begin{array}{l}\text { Participation in } \\
\text { problem scoping } \\
\text { and providing } \\
\text { information. }\end{array}$ \\
\hline $\begin{array}{l}\text { Scheme selection } \\
\text { and development }\end{array}$ & $\begin{array}{l}\text { Months to years } \\
\text { prior to scheme } \\
\text { implementation. }\end{array}$ & $\begin{array}{l}\text { Examining policy options } \\
\text { and consulting with } \\
\text { stakeholders. }\end{array}$ & $\begin{array}{l}\text { Participation in } \\
\text { consultation, } \\
\text { lobbying for } \\
\text { preferred option. }\end{array}$ \\
\hline Establishment & $\begin{array}{l}\text { Immediately prior } \\
\text { to landholder } \\
\text { engagement. }\end{array}$ & $\begin{array}{l}\text { Staff training, equipment, } \\
\text { systems set-up, advertise } \\
\text { and promote. }\end{array}$ & $\begin{array}{l}\text { Gathering } \\
\text { information } \\
\text { about scheme, } \\
\text { and preparation } \\
\text { to engage. } \\
\end{array}$ \\
\hline $\begin{array}{l}\text { Implementation } \\
\text { (including } \\
\text { repeated } \\
\text { implementation) }\end{array}$ & $\begin{array}{l}\text { Initial selection and } \\
\text { contracting phase - } \\
\text { repeated as needed. }\end{array}$ & $\begin{array}{l}\text { Engage with and process } \\
\text { participants, negotiate } \\
\text { contracts, etc. }\end{array}$ & $\begin{array}{l}\text { Engage with } \\
\text { scheme, prepare } \\
\text { proposals, } \\
\text { negotiate } \\
\text { contracts, etc. }\end{array}$ \\
\hline $\begin{array}{l}\text { Scheme } \\
\text { management }\end{array}$ & $\begin{array}{l}\text { Ongoing scheme } \\
\text { management } \\
\text { such as making } \\
\text { payments, basic } \\
\text { reporting, and so on. }\end{array}$ & $\begin{array}{l}\text { Make payments, record } \\
\text { keeping, engagement as } \\
\text { required. }\end{array}$ & $\begin{array}{l}\text { Reporting, } \\
\text { record keeping. }\end{array}$ \\
\hline $\begin{array}{l}\text { Landholder } \\
\text { monitoring and } \\
\text { compliance }\end{array}$ & $\begin{array}{l}\text { After contracting } \\
\text { - auditing and } \\
\text { any enforcement } \\
\text { required. }\end{array}$ & $\begin{array}{l}\text { Auditing and verifying } \\
\text { reporting, any } \\
\text { compliance activities. }\end{array}$ & $\begin{array}{l}\text { Defence of } \\
\text { compliance } \\
\text { activities, } \\
\text { additional } \\
\text { reporting, etc. }\end{array}$ \\
\hline $\begin{array}{l}\text { Ecological } \\
\text { monitoring and } \\
\text { evaluation }\end{array}$ & $\begin{array}{l}\text { Before, during } \\
\text { and after scheme } \\
\text { (length depends on } \\
\text { ecological response } \\
\text { time). }\end{array}$ & $\begin{array}{l}\text { Data collection and } \\
\text { evaluation of ecological } \\
\text { outcomes (relative to } \\
\text { problem formulation). }\end{array}$ & $\begin{array}{l}\text { Likely to be } \\
\text { relatively low. }\end{array}$ \\
\hline $\begin{array}{l}\text { Scheme } \\
\text { evaluation and } \\
\text { improvement }\end{array}$ & $\begin{array}{l}\text { During and after } \\
\text { contract completion. }\end{array}$ & $\begin{array}{l}\text { Incurred in analysis of } \\
\text { effectiveness, making } \\
\text { and implementing } \\
\text { recommendations. }\end{array}$ & $\begin{array}{l}\text { Lobbying } \\
\text { for scheme } \\
\text { changes, etc. }\end{array}$ \\
\hline
\end{tabular}

These costs will vary from scheme to scheme depending on:

- The type of transaction (e.g. simple versus complex, once-off or long-term) which is linked to the type of scheme. It will also depend on transaction uniqueness, frequency, and uncertainty in various 
elements, including ease of observing actions and outcomes, timelags to environmental effects.

- Who is involved in the transaction - especially their prior experience, opportunism or extent of self-interested strategic behaviour.

- Other influences including previous and other policy and procedures, trust in administrators, comfort with policy principles and social connectedness (Coggan et al. 2010).

Two recent themes in the transaction cost literature have refined our understanding of transaction costs in agri-environment schemes. Firstly, transaction costs have a dynamic element through time (which partly covers our earlier point about when transaction costs can be considered sunk and thus irrelevant to informing current decisions) as the effectiveness of instruments through time and under different demands will change with experience, technology, and other factors (Arrow 1962; Falconer et al. 2001; Fang et al. 2005; McCann et al. 2005). This is particularly relevant to trading schemes, but could also apply to impacts of technological change on, for example, monitoring in grant schemes.

Secondly, a broader emphasis has arisen towards the role of transaction costs in evaluating overall policy efficiency, rather than on measuring transaction costs in isolation (see Pannell et al. 2013, for example). There are a number of very good studies either stepping through the process of measuring the transaction costs of agri-environmental and broader environmental policy (see McCann et al. 2005; Kuperan et al. 2008) or measuring transaction costs from actual schemes (see Falconer and Saunders 2002; Mettepenningen and Van Huylenbroeck 2009; Ofei-Mensah and Bennett 2013).

\section{Transaction costs are not trivial}

A number of researchers have directed their attention toward the empirical assessment of transaction costs across a wide range of settings. Estimates of transaction costs to scheme administrators and proponents have ranged from $<1-100$ per cent of the payments made to scheme participants. For instance, studies carried out in the US show that public transaction costs represent a substantial part of total costs 
incurred in designing a policy objective, with a magnitude ranging from 8 per cent of the water purchase cost (Howitt 1994) to 38 per cent of the agricultural assistance program (McCann et al. 2005). Public administration transaction costs of agri-environmental schemes across Europe was initially 102 per cent of payments to landholders (1992/93) but declined over time to 18 per cent (1998/99) (Falconer et al. 2001). Mettepenningen and Van Huylenbroeck (2009) explicitly look at private transaction costs of an agri-environmental scheme and report that, on average, these are 15 per cent of the total cost of the policy.

Recent Australian estimates have indicated that the average transaction costs amount to nearly $\$ 8,400$ for Reef Rescue participants (average total transaction cost per farm was 38 per cent of average funding provided) (Coggan et al. 2014). On the proponent and administrator side of the equation, Binney et al. (2010) indicate that the costs to the Australian Government of the Environmental Stewardship Program was around 10 per cent, and the (Tasmanian) Forest Conservation Fund was around 11 per cent of total scheme costs, although these exclude some elements of investigation, design, and establishment. Our own experience with one regional Victorian catchment management authority with substantial experience in agri-environment scheme delivery identified ongoing transaction costs (i.e. only implementation, scheme management, and some elements of monitoring and compliance) of around 10 per cent of total costs for a tendering program, and 95 per cent of program costs for a parallel grant scheme. Differences resulted from the grant scheme funding smaller projects, requiring a minimum cost-share from landholders, and apparently requiring additional recruitment effort into a less flexible program.

So we can see that transaction costs are likely to vary across applications and the type of scheme implemented. In Table 16.2, we set out some of the likely differences in costs across different types of agri-environment schemes, namely grants (rule-based allocation of funds, often with or without consideration of cost-effectiveness), tendering or reverse auction approaches (funds allocated competitively to landholder applicants based on relative costeffectiveness), and offset schemes (usually negotiated contracts with landholders). We note that indicating the per unit costs is difficult because transaction costs are made up of fixed and variable costs. Fixed costs are not strongly influenced by the amount of payments or participants, while variable costs are directly related to participation. 


\section{Table 16.2: Likely differences in transaction costs between agri-environmental payment approaches.}

\begin{tabular}{|c|c|c|c|}
\hline Transaction cost & Grants & Conservation tenders & Offset payments \\
\hline $\begin{array}{l}\text { Information about } \\
\text { the problem }\end{array}$ & \multicolumn{3}{|c|}{$\begin{array}{l}\text { Costs unlikely to differ across schemes, although there will } \\
\text { likely be additional lobbying and consultation costs in two-sided } \\
\text { markets, such as offsets. }\end{array}$} \\
\hline $\begin{array}{l}\text { Scheme selection } \\
\text { and development }\end{array}$ & $\begin{array}{l}\text { Usually can be } \\
\text { adapted from } \\
\text { existing approach } \\
\text { (likely to be less } \\
\text { reliance on metric } \\
\text { for assessment). } \\
\end{array}$ & $\begin{array}{l}\text { Greater costs in bid } \\
\text { assessment and } \\
\text { possibly in differential } \\
\text { contracts. }\end{array}$ & $\begin{array}{l}\text { Design of } \\
\text { more rigorous } \\
\text { assessments on } \\
\text { both market sides } \\
\text { and potentially a } \\
\text { trading mechanism. }\end{array}$ \\
\hline Establishment & $\begin{array}{l}\text { Existing } \\
\text { processes with } \\
\text { specialised } \\
\text { advertising and } \\
\text { engagement. }\end{array}$ & $\begin{array}{l}\text { Specialised advertising } \\
\text { and engagement, new } \\
\text { systems to receive and } \\
\text { rank bids. Often more } \\
\text { detailed training for } \\
\text { field assessment. }\end{array}$ & $\begin{array}{l}\text { Detailed registry } \\
\text { often required } \\
\text { in addition to } \\
\text { measurement } \\
\text { systems. Sometimes } \\
\text { trust arrangements } \\
\text { for funds. }\end{array}$ \\
\hline $\begin{array}{l}\text { Implementation } \\
\text { (including repeated } \\
\text { implementation) }\end{array}$ & $\begin{array}{l}\text { Site visits remain } \\
\text { expensive. } \\
\text { Covenants } \\
\text { uncommon. }\end{array}$ & $\begin{array}{l}\text { Any field assessment } \\
\text { will remain relatively } \\
\text { expensive. More } \\
\text { detailed contract, } \\
\text { engagement. } \\
\text { Covenants incur } \\
\text { substantial time and } \\
\text { legal costs where } \\
\text { relevant. }\end{array}$ & $\begin{array}{l}\text { Unlikely to differ } \\
\text { substantially } \\
\text { from tenders, but } \\
\text { continue to be } \\
\text { incurred whilst } \\
\text { tenders tend } \\
\text { to be one-off } \\
\text { events. Covenants } \\
\text { almost universally } \\
\text { required and } \\
\text { incur substantial } \\
\text { transaction costs. }\end{array}$ \\
\hline $\begin{array}{l}\text { Scheme } \\
\text { management }\end{array}$ & $\begin{array}{l}\text { Depends on } \\
\text { scheme design, } \\
\text { but usually low. }\end{array}$ & $\begin{array}{l}\text { Landholders may need } \\
\text { to submit detailed } \\
\text { annual reports. May be } \\
\text { ongoing payments. }\end{array}$ & $\begin{array}{l}\text { Ongoing cost } \\
\text { of finding and } \\
\text { negotiating with } \\
\text { offset supplier, } \\
\text { making payments } \\
\text { and conducting } \\
\text { reporting. }\end{array}$ \\
\hline \multirow[t]{2}{*}{$\begin{array}{l}\text { Landholder } \\
\text { monitoring and } \\
\text { compliance }\end{array}$} & $\begin{array}{l}\text { Often little or no } \\
\text { landholder self- } \\
\text { monitoring. }\end{array}$ & $\begin{array}{l}\text { Usually at least some } \\
\text { landholder self- } \\
\text { monitoring. }\end{array}$ & $\begin{array}{l}\text { Usually at least } \\
\text { some offset provider } \\
\text { ongoing self- } \\
\text { monitoring required. }\end{array}$ \\
\hline & \multicolumn{3}{|c|}{$\begin{array}{l}\text { Compliance monitoring is low across all schemes in practice but } \\
\text { should logically be higher for more complex and ongoing schemes. }\end{array}$} \\
\hline $\begin{array}{l}\text { Ecological } \\
\text { evaluation and } \\
\text { program evaluation } \\
\text { and improvement }\end{array}$ & \multicolumn{3}{|c|}{$\begin{array}{l}\text { Highly dependent on whether the scheme is formally evaluated or } \\
\text { repeated. Will usually be higher for a trading mechanism because } \\
\text { it is explicitly ongoing but so little is done in practice that costs } \\
\text { unlikely to differ. }\end{array}$} \\
\hline
\end{tabular}


So which costs are likely to matter most? Available data mostly focuses on costs from the establishment stage onwards. For example, the National Market Based Instruments Pilots program (BDA Group 2009) and Binney et al. (2010) focus on costs to government and natural resource management (NRM) groups once a particular approach has been selected. Most of these establishment costs are likely to be fixed (though investment in human skills can be easily lost). The major transaction costs to government are likely to be implementation costs, particularly where site visits and heterogeneous or customised contracts are required. While transaction costs such as these are often unavoidable, some measures can be taken to reduce the cost. Retaining corporate knowledge on processes and data collection methodologies for site visits is one solution. Targeting schemes to critical landholders where customised contracts are required is another. Metric design is often thought to be expensive, but was less than 1 per cent of the environmental stewardship program budget (Binney et al. 2010). Good data storage and use of corporate knowledge could have been contributing factors here. On the private side, transaction costs appear to be driven by complexity of both the scheme and the individual interaction required more than scheme type, although there are few studies that actively examine the differential aspects of transaction costs (see Chapter 21 for some insights on conservation tenders, for example). Timely, clear and consistent communication of scheme requirements by the administrator, along with easy access to information for private parties, can significantly reduce private transaction costs (Coggan et al. 2013).

\section{Conclusions}

Transaction costs for agri-environment schemes are the cost of time and effort, as well as direct expenditure incurred in scheme investigation, design, implementation, management and administration, and monitoring and evaluation. The scale and distributional burden of transaction costs should be carefully considered alongside other costs and benefits from agri-environment schemes, as an essential element of understanding whether government policy is efficient, or at least cost-effective. Of course, in some settings, some costs are sunk and should not be considered in an analysis of the comparative efficiency of different schemes. Hence, it is important for scheme proponents 
and designers to identify which are likely to be the most important transaction costs, who bears them, and how they impact on different elements of scheme design or implementation.

The purpose of considering transaction costs is not necessarily to minimise or reduce them. Instead, a focus on efficient program design may require increased transaction costs in order to focus more closely on delivering the desired outcome. That is, different program designs will have different implications for transaction costs and overall efficiency. Despite the increasing number of transaction costs analyses, none focus on the potential for efficiency dividends to be achieved from higher transaction costs, and this would seem to be a particularly useful area to explore given the emphasis on minimising delivery overheads. Delivery and implementation of agri-environment schemes can benefit from a closer focus on transaction costs.

\section{References}

Arrow, K.J. (1962) 'Economic welfare and the allocation of resources for invention', The rate and direction of inventive activity: Economic and social factors (ed. R.R. Nelson), Princeton, Princeton University Press.

BDA Group (2009) Final report of the National Market Based Instruments Pilot Program, prepared for the Department of Agriculture, Fisheries and Forestry.

Binney, J., K. Whiteoak and G. Tunny (2010) Review of the Environmental Stewardship Program, Marsden Jacob and Associates, Available at: www.nrm.gov.au/resources/publications/stewardship/esp-review. html.

Coggan, A., E. Buitelaar, S.M. Whitten and J. Bennett (2013) ‘Factors that influence transaction costs in development offsets: Who bears what and why?', Ecological Economics 88: 222-31.

Coggan, A., M. van Grieken, A. Boullier and X. Jardi (2014) 'Private transaction costs of participation in water quality improvement programs for Australia's Great Barrier Reef: Extent, causes and policy implications', Australian Journal of Agricultural and Resource Economics 59(4): 499-517. 
Coggan, A., S.M. Whitten and J. Bennett (2010) 'Influences of transaction costs in environmental policy', Ecological Economics 69: 1777-84.

Falconer, K. and C. Saunders (2002) 'Transaction costs for SSSIs and policy design', Land Use Policy 19:157-166.

Falconer, K., P. Dupraz, M. Whitby (2001) 'An investigation of policy administrative costs using panel data for the English environmentally sensitive areas', Journal of Agricultural Economics 52: 83-103.

Fang, F., K.W. Easter and P.L. Brezonik (2005) 'Point-non-point source water quality trading: A case study in the Minnesota River Basin', Journal of American Water Resources Association 41: 645-58.

Howitt, R.E. (1994) 'Empirical analysis of water market institutions: The 1991 California water market', Resource and Energy Economics $16,357-71$.

Kuperan, K., N.M.R. Abdullah, R.S. Pomeroy, E.L. Genio and A.M. Salamanca (2008) 'Measuring transaction costs of fisheries co-management', Coastal Management 36: 225-40.

McCann, L., B. Colby, K.W. Easter, A. Kasterine and K.V. Kuperan (2005) 'Transaction cost measurement for evaluating environmental policies', Ecological Economics 52: 527-42.

Mettepenningen, E. and C. Van Huylenbroeck (2009) 'Factors influencing private transaction costs related to agri-environmental schemes in Europe', Multifunctional rural land management: Economics and policies (eds F. Bruwer and M. van der Heide), Earthscan, London, pp. 145-68.

North, D.C. (1990) Institutions, institutional change and economic performance, Cambridge University Press, Cambridge.

Ofei-Mensah, A. and J. Bennett (2013) 'Transaction costs of alternative greenhouse gas policies in Australian transport energy sector', Ecological Economics 88: 214-21.

Ostrom, E. (1990) Governing the commons: The evolution of institutions for collective action, Cambridge, Cambridge University Press. 
Pannell, D.J., A.M. Roberts, G. Park and J. Alexander (2013) 'Improving environmental decisions: A transaction-costs story', Ecological Economics 88: 244-52.

Reeson, A.F., L.C. Rodriguez, S.M. Whitten, et al. (2011) 'Adapting auctions for the provision of ecosystem services at the landscape scale', Ecological Economics 70: 1621-7.

Williamson, O.E. (1998) 'Transaction cost economics: How it works; where it is headed', De Economist 146(1): 23-58. 
This text is taken from Learning from agri-environment schemes in Australia: Investing in biodiversity and other ecosystem services on farms, edited by Dean Ansell, Fiona Gibson and David Salt, published 2016 by ANU Press, The Australian National University, Canberra, Australia. 